\title{
An Assessment of the Diversity of Indigenous Forage Plant Species of the Dry Season in Dry lands of North Western Ethiopia: Implication for their Conservation and Sustainable Use
}

\author{
Dereje Mosissa $^{1 *}$, Melak Agajie ${ }^{2}$, Dejene Reda ${ }^{1}$ \\ ${ }^{\mathrm{T}}$ Ethiopian Biodiversity Institute Assosa Biodiversity Center Forest and Rangeland Biodiversity Case Team \\ ${ }^{2}$ Ethiopian Biodiversity Institute Assosa Biodiversity Center Director and Researcher in Crop and Horticulture \\ Biodiversity Case Team
}

*Corresponding Author

Dereje Mosissa

\section{Article History}

Received: 17.12 .2020

Accepted: 31.12 .2020

Published: 06.01.2021

\begin{abstract}
This study was done to assess the diversity of indigenous forage plants of the dry season in CombretumTerminalia woodlands of Guba District, North West of Ethiopia. A total of 69 species of plants were identified and of which all are consumed as a feed resource by the local animal breeds during dry season. The diversity $(\mathrm{H})$ values of the forage plant species ranged between 0.65 to 1.67 across the plots sampled. The similarities (J) between the plots in terms of species composition of all forage species were 0.56 and 0.94 . The evenness $(\mathrm{E})$ values of all forage species were in between 0.78 and 0.86 across the sampled plots. The densities of all forage species, including seedlings, were 1216 stems $\mathrm{ha}^{-1}$. In the study area Combretum colinum, Lonchocarpus laxiflorus, Terminalia laxiflora, Acacia polycantha and Ziziphus mисronata were the five relatively abundant forage species. The Importance Value Index (IVI) values of all the forage species ranged between 0.31 (Strychnos innocua) and 81.67 (Combretum colinum). Particularly local goat breeds of the study area were known to feed on various plant resources than other breeds. Moreover, Bigariya local cattle breeds were also know to feed on various similar plant resources hence adapted to harsh environmental condition known in western Ethiopia. Pounded barks of Cordia Africana and roots of Securidaca longepedankulata is used in treatment of diarrhoea and common cold cases of goats. Moreover the sheath of Hyphenea thebiaca is used to treat the eye disease of Goats, sheep and cattle.
\end{abstract}

Keywords: Bigariya cattle, density, diversity, evenness, frequency, Importance Value Index.

\section{INTRODUCTION}

Rangelands are defined as those areas of the world, which by reasons of physical limitation, low and erratic precipitation, rough topography, poor drainage, or cold temperatures are unsuited for cultivation and which are a source of forage for free ranging native and domestic animals, as well as a source of wood products, water and wildlife [1]. Of these, extensive livestock production is the major land use on rangelands with large areas of land required per head of livestock [2]. Accordingly, the condition of the rangelands which Trollope et al., [3] defined; the state of health of the rangeland in terms of its ecological status, resistance to soil erosion and potential for producing forage for sustained optimum livestock production must be investigated. Furthermore, rangeland condition is a function of all plant forms (trees, grasses and shrubs) that occur in it [4]. Rangeland condition cannot, therefore, be simply indexed according to its usefulness for a single priority land use. As with grassland, the composition and structure of each of the other components vary, which adds an extra and complicating dimension to rangeland assessment. In addition, the rangeland is frequently used by pastoralists who own different animal types (browsers and grazers). Assessment techniques need to consider the different vegetation components for the proper utilization of the available rangeland resources. Until recent times, research on rangeland dynamics has historically focused on the effects of various management practices on forage production and animal response, with little attention given to the impact of grazing on the condition of the soil. Since animal production is directly related to rangeland condition, rangeland degradation will result in a lower income [5].

Copyright (C) 2020 The Author(s): This is an open-access article distributed under the terms of the Creative Commons Attribution 4.0 International License (CC BY-NC 4.0) which permits unrestricted use, distribution, and reproduction in any medium for non-commercial use provided the original author and source are credited. 
In Western Ethiopia, semi-pastoralists of different ethnic groups are found predominately in BenishangulGumuz Regional State (BGRS) which are primarily dependent on natural range based livestock production. Even though the study areas have a vast area of rangeland, there was no research study undertaken to assess the condition of the rangelands and take appropriate management interventions in relation to livestock production. Accordingly, the objective of this study was to assess the forage resource diversity and condition of the grazing by livestock in the mentioned study district.

\section{MATERIALS AND METHODS \\ Description of the study area}

The study was conducted in one district (Guba) which was purposely selected from Benishangul-Gumuz Regional State western Ethiopia. Benishangul-Gumuz Regional State. GubaWoreda is one of the 20 woredas in the Benishangul-GumuzRegion of Ethiopia. It is located $894 \mathrm{~km}$ northwest of Addis Ababa and about $220 \mathrm{~km}$ northeast of Assosa, the capital city of Benishangul-Gumuz Regional State. The district is geographically located at ' $11^{\circ} 16^{\prime} 0^{\prime \prime} \mathrm{N}$ latitude and $35^{\circ} 17^{\prime} 0^{\prime \prime}$ E longitude.It is a part of the Metekel Zone, Guba is bordered by the Abay River on the south which separates it from the Kamashi Zone, Sudan on the west, Amhara Region on the north, Dangur on the east, and on the southeast by the Beles River, which separates it from Wenbera [6].

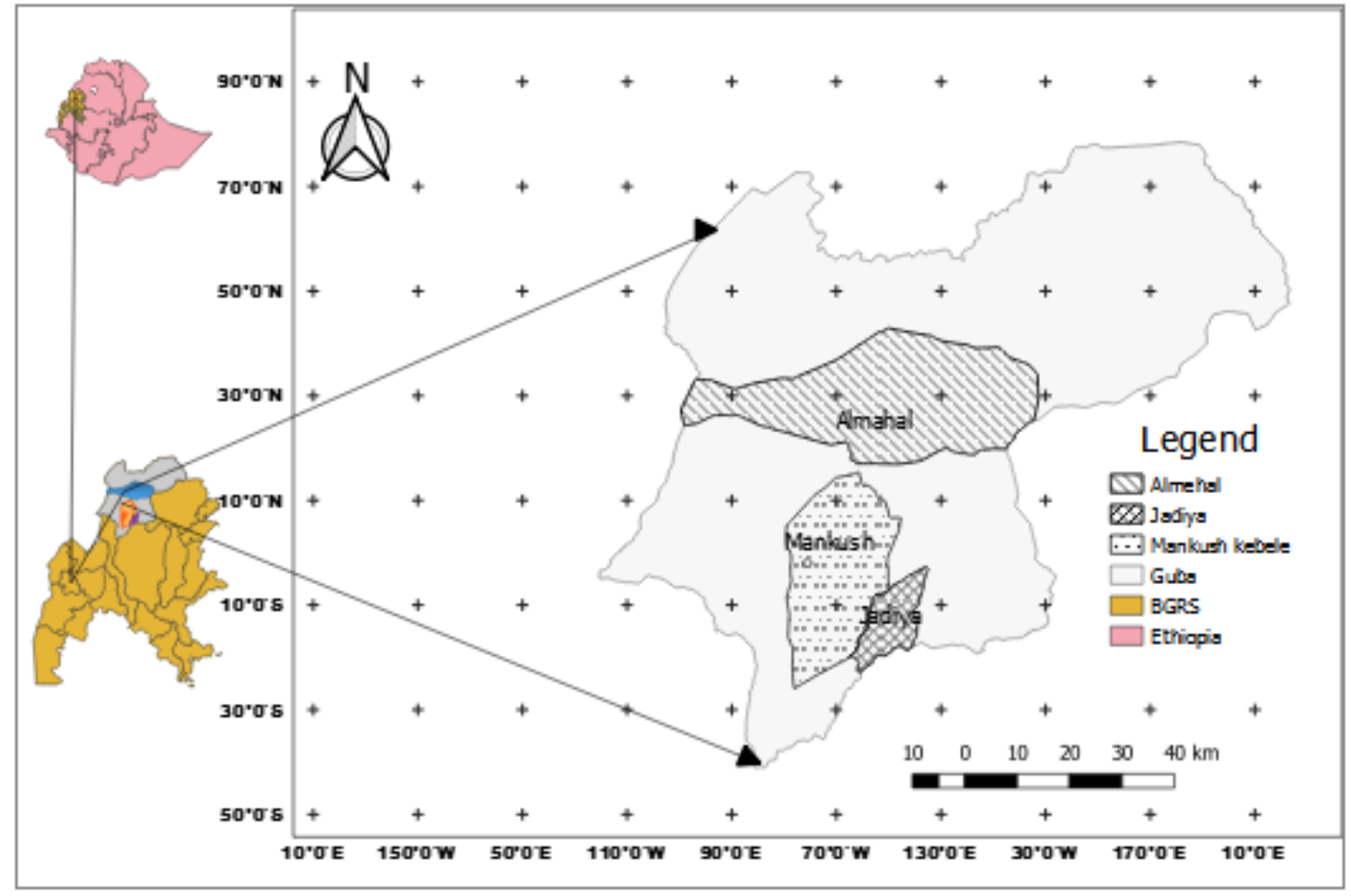

Fig-1: Map of the study area

\section{STUDY METHODOLOGY}

Formal surveys were conducted in Guba district in 2020 dry seasons, as part of the diagnostic first phase. "The potential of crop residues and natural vegetation as ruminant feeds during the dry season in Guba district of Benishangul Gumuz Regional State". The district is in the semi-humid zone. A total of $100(20 \mathrm{~m} \mathrm{£} 20 \mathrm{~m})$ sample plots were laid along the transect lines, following the procedures described by Kent and Coker [7]. In each plot, the identity, number of individuals, diameter at breast height (DBH) and height of all woody species having a height above $1.5 \mathrm{~m}$ were recorded.

A total of 30 structured questionnaires were developed and used. Only the crop/livestock farmers from the selected kebeles were interviewed. The respondent was the household head. Information from the questionnaire, related to utilization of trees and shrubs and other natural vegetation, were coded and summarized using a SPSS calculator. Before social survey field assessment was done to identify the overall vegetation type and feed materials by the live stocks on field. A total of 12 sample plots were taken to visualize and represent the vegetation of the area.

\section{Forage Preference by Livestock}

Direct observation of animals using feeding minutes (Bgugstadet al., 1970) was adopted to assess forage preference by timing the animal as they feed. Moreover, cattle owners were interviewed to rank the mostly preferred species by their livestock's. 


\section{Statistical Analyses}

Diversity of all woody species was determined using the Shannon - Wiener Diversity Index (H) and evenness

(E) [7]. Jaccard's Similarity Coefficient $\left(\mathrm{S}_{\mathrm{j}}\right)$ was used to compute similarity in woody species composition of the area. The indices were computed using the following formulas:

$$
\mathrm{H}=-\sum_{i=1}^{S} P i \ln p i
$$

Where $\mathrm{H}=$ Shannon - Wiener diversity index and $\mathrm{P}_{\mathrm{i}}=$ the proportion of individuals found in the $\mathrm{i}^{\text {th }}$ species;

$$
\mathrm{E}=\frac{H}{\operatorname{Hmax}}=\frac{H}{\ln s^{\prime}}
$$

Where $\mathrm{E}=$ evenness, $\mathrm{H}_{\max }$ is the maximum level of diversity possible within a given population, which equals $\ln$ (number of species); and

$$
\mathrm{J}=\frac{C}{A+B+C}
$$

Where $\mathrm{J}=$ Jaccard's similarity coefficient, $\mathrm{C}=$ the number of species common to both sites, $\mathrm{A}=$ the number of species present in one of the sites to be compared and $\mathrm{B}$ is the number of species present in the other site.

Density was calculated by converting the total number of individuals of each species to equivalent numbers per hectare (absolute density), and as the percentage of the absolute density of each species divided by the total stem number of all species ha ${ }^{-1}$ (relative density). Frequency distribution of each species was determined from the number of plots in which the species was recorded (absolute frequency) [7], and as a percentage (relative frequency) by dividing the absolute frequency of the species by the sum of the absolute frequencies of all the species. The absolute dominance of woody species with DBH $2.5 \mathrm{~cm}$ was determined from summing the basal area (BA) of all individuals of a species. Relative dominance was calculated as the percentage of the BA of a species divided by the total BA of all species.

The relative ecological importance of each woody species, commonly referred to as Important Value Index (IVI), was determined by summing its relative frequency, relative density and relative dominance [7].

The population structures woody vegetation and that of forage woody species was assessed from the frequency distribution of diameters based on histograms constructed by grouping all individuals of each woody species into the following successive diameter classes: $1=0-10,2=10-20,3=20-30,4=30-40$ and $5>40 \mathrm{~cm}[8-11]$. The data were analyzed using Biodiversity Professional Software version 8.2.

Plant identification was carried out mostly in the field, and for those species, which could not be identified in the field, herbarium voucher specimens were prepared, transported to and identified in the Ethiopian Biodiversity Institute Herbarium. Plant nomenclature in this article follows the published volumes of Flora of Ethiopia, and Flora of Ethiopia and Eritrea [12-15].

\section{RESULTS AND DISCUSSION \\ Species Richness}

As it was observed on field survey that the woodland vegetation of Guba district is characterized by small to moderately sized trees, herbs, grasses and sedges. The ground cover is dominated by herbaceous geophytes at the beginning of rainy season (May and June). Towards the end of rainy season (September to November) tall strata perennial grasses become dominant. A total of 69 plant species were recorded in the study area of which all are consumed as a feed resource by the local breeds during dry season (Table-1). 
Dereje Mosissa et al., South Asian Res J Bio Appl Biosci; Vol-3, Iss-1 (Jan-Feb, 2021): 1-10

Table-1: List of some common plant species encountered in Guba district

\begin{tabular}{|c|c|c|c|}
\hline No & Local Name (Gumuzigna) & Botanical Name & Family \\
\hline 1 & Achiquwa & Leonotis nepetifolia & Lamiaceae \\
\hline 2 & Amberta & Andropogon schirensis & Poaceae \\
\hline 3 & Adegila & Streospermum kunthianum & Bigniniaceae \\
\hline 4 & Anderkukuwa & Strychnose spinosa & Loganiaceae \\
\hline 5 & Hanguga/Hangua & Ziziphus abyssinica & Rhamnaceae \\
\hline 6 & Siya/Gaba & Ziziphus mucronata & Rhamnaceae \\
\hline 7 & Antsiqina Guanja & Cissus cornifolia & Vitaceae \\
\hline 8 & Antutiya & Solanum alatum & Solanaceae \\
\hline 9 & Babegoha/Bogoha & Terminalia macroptera & Combretacaea \\
\hline 10 & Babenga & Hyphaene thebiaca & Arecaceae \\
\hline 11 & Bambeluwa & Entada africana & Fabaceae \\
\hline 12 & Bambuta & Annona senegalensis & Annonaceae \\
\hline 13 & Banja & Cordia africana & Boraginaceae \\
\hline 14 & Banshzegona & Wissadula rostrata & Malvaceae \\
\hline 15 & Bebdaja & Tragia doryodes & Euphorbiacea \\
\hline 16 & Bewa & Lonchocarpus laxiflorus & Fabaceae \\
\hline 17 & Begiya & Strychnos innocua & Loganiacea \\
\hline 18 & Bora & Terminalia laxiflora & Combretaceae \\
\hline 19 & Bembeda & Maytenus senegalensis & Celastraceae \\
\hline 20 & Bidiguwa & Hyparrhenia anthistirioides & Poaceae \\
\hline 21 & Biilga & Lannea welweschii & Anacardiaceae \\
\hline 22 & Yempite & Lannea fruticosa & Anacardiaceae \\
\hline 23 & Mamusa & Cymbopopogon caesuis & Poacea \\
\hline 24 & Chaya & Pterocarpus lucens & Fabaceae \\
\hline 25 & Dijiha & Breonadia salicina & Rubiacea \\
\hline 26 & Diwa & Syzygium guineense & Myrtaceae \\
\hline 27 & Dhoga & Tamarindus indica & Fabaceae \\
\hline 28 & Mecha & Piliostigma thonningii & Fabaceae \\
\hline 29 & Fuqa & Ficus sycomorus & Moraceae \\
\hline 30 & Eboba & Rottboellia cochinchinensis & Poaceae \\
\hline 31 & Asiya & Ficus lutea & Moraceae \\
\hline 32 & Bambichowa & Asparagus flagellaris & Asparagaceae \\
\hline 33 & Engifa & Combretum collinum & Combretaceae \\
\hline 34 & Elta/Enta & Oxytenanthera abyssinica & Poacea \\
\hline 35 & Ephuwa & Sterculia africana & Sterculiaceae \\
\hline 36 & Etissayaquwa & Pennisetum thumbergii & Poacea \\
\hline 37 & Gideya & Grewia velutina & Tiliacea \\
\hline 38 & Goha & Phoenix reclinata & Aracaceae \\
\hline 39 & Golgola & Boswellia papyrifera & Burseraceae \\
\hline 40 & Hesiniya & Hyparrhenia filipendula & Poacea \\
\hline 41 & Heya & Ximenia americana & Olacaceae \\
\hline 42 & Jiggnewiya & Clerodendrum alatum & Verbanacea \\
\hline 43 & Jipiwa/Chamda & Combretum hartmanianum & Combretacea \\
\hline 44 & Liffa & Luffa cylinderica & Cucurbitacea \\
\hline 45 & Machanchiga & Lagenaria siceraria & Cucurbitacea \\
\hline 46 & Meela & Acacia seyal & Fabacea \\
\hline 47 & Mejira & Trigonella foenum-graecum & Fabaceae \\
\hline 48 & Meetsiya & Tristemma mauritianum & Melastomataceae \\
\hline 49 & Piwe & Crossopteryx febrifuga & Rubiacea \\
\hline 50 & Qota & Balanitus aegyptiaca & Balanitaceae \\
\hline 51 & Quatsirqa & Acacia hecatophylla & Fabaceae \\
\hline 52 & Sasiqida & Cynodon nlemfuensis & Poacea \\
\hline 53 & Sipe & Acasia polyacantha & Fabaceae \\
\hline 54 & Siqida/Si-Eda & Securidaca longepedunculata & Polygalaceae \\
\hline 55 & Songah & Ziziphus mauritiana & Rhamnaceae \\
\hline 56 & Tisheza & Vitex doniana & Verbanaceae \\
\hline 57 & Dimquri & Ipomoea eriocarpa & Convolvulaceae \\
\hline 58 & Tara/Geret & Acacia senegal & Fabaceae \\
\hline 59 & Mureb & Pennisetum unisetum & Poacea \\
\hline 60 & Kota & Gardenia ternifolia & Rubiacea \\
\hline 61 & Weela & Dicrostachus cinerea & Fabacea \\
\hline 62 & Weela & Flueggea virosa & Euphorbiaceae \\
\hline 63 & Sigah & Anogeissus leiocarpa & Combretaceae \\
\hline 64 & Insiya & Ficus vasta & Moraceae \\
\hline 65 & Duruba & Dalbergia melanoxylon & Fabaceae \\
\hline 66 & & Saspania spp & Fabaceae \\
\hline 67 & Dadiha & Acanthus polystachyus & Acanthaceae \\
\hline 68 & Ansisiwa & Albizia malacophylla & Fabaceae \\
\hline 69 & Unkown & Vernonia purpurea & Asteracea \\
\hline
\end{tabular}




\section{Diversity of forage plant species of the drier season in the study area}

The diversity $(\mathrm{H})$ values of the forage plant species ranged between 0.65 to 1.67 across the plots sampled. The similarities $(\mathrm{J})$ between the plots in terms of species composition of all forage species were 0.56 and 0.94 . The evenness (E) values of all forage species were in between 0.78 and 0.86 across the sampled plots (Table-2). The numbers of forage plant species recorded at the study sites are comparable to those reported from Gambella, southwestern Ethiopia [16] and Yabello, southern Ethiopia [17].

Table-2: List of forage plant species encountered in the study area with their IVI values

\begin{tabular}{|c|c|c|c|c|c|c|c|c|}
\hline Botanical Name & Family & DE & RDE & DO & RDO & FR & RFR & IVI \\
\hline Acacia polycantha & Fabaceae & 45 & 13.21 & 7.24 & 39.02 & 59 & 10.01 & 62.24 \\
\hline Acacia seyal & Fabaceae & 78 & 20.85 & 1.02 & 15.79 & 80 & 17.2 & 53.84 \\
\hline Streospermum kunthianum & Bigniniaceae & 7 & 1.65 & 1.05 & 5.96 & 83 & 13.7 & 21.31 \\
\hline Strychnose spinosa & Loganiaceae & 62 & 13.04 & 2.4 & 13.6 & 78 & 12.9 & 39.54 \\
\hline Ziziphus abyssinica & Rhamnaceae & 70 & 14.21 & 2.13 & 12.1 & 66 & 10.89 & 37.2 \\
\hline Ziziphus mucronata & Rhamnaceae & 76 & 6.65 & 1.44 & 8.15 & 49 & 8.09 & 22.89 \\
\hline Cissus cornifolia & Vitaceae & 23 & 7.6 & 0.31 & 1.77 & 51 & 8.42 & 17.79 \\
\hline Acacia hecatophylla & Fabaceae & 61 & 14.34 & 1.69 & 13.94 & 37 & 13.11 & 41.39 \\
\hline Terminalia macroptera & Combretacaea & 50 & 15.5 & 0.21 & 13.19 & 34 & 25.61 & 54.3 \\
\hline Hyphaene thebiaca & Arecaceae & 48 & 22.82 & 6.3 & 25.52 & 26 & 14.29 & 62.63 \\
\hline Entada africana & Fabaceae & 17 & 11.65 & 0.08 & 0.48 & 14 & 2.31 & 14.44 \\
\hline Annona senegalensis & Annonaceae & 26 & 10.05 & 0.18 & 1.01 & 12 & 1.98 & 13.04 \\
\hline Cordia africana & Boraginaceae & 1 & 0.11 & 0.49 & 2.78 & 2 & 0.33 & 3.22 \\
\hline Wissadula rostrata & Malvaceae & 4 & 0.75 & 0.01 & 0.08 & 10 & 1.65 & 2.48 \\
\hline Tragia doryodes & Euphorbiacea & 1 & 0.11 & 0.18 & 1.01 & 2 & 0.33 & 1.45 \\
\hline Lonchocarpus laxiflorus & Fabaceae & 89 & 16.05 & 0.03 & 15.62 & 1 & 16.47 & 48.14 \\
\hline Strychnos innocua & Loganiacea & 1 & 0.11 & 0 & 0.03 & 1 & 0.17 & 0.31 \\
\hline Terminalia laxiflora & Combretaceae & 76 & 19.65 & 0 & 32.26 & 1 & 25.26 & 77.17 \\
\hline Maytenus senegalensis & Celastraceae & 12 & 8.02 & 1.8 & 10.04 & 14 & 11.1 & 29.16 \\
\hline Acacia senegal & Fabaceae & 13 & 4.9 & 3.04 & 34.91 & 20 & 10.99 & 50.8 \\
\hline Lannea welweschii & Anacardiaceae & 62 & 24.21 & 0.64 & 7.37 & 33 & 18.13 & 49.71 \\
\hline Lannea fruticosa & Anacardiaceae & 50 & 19.69 & 1.07 & 12.23 & 19 & 10.44 & 42.36 \\
\hline Dicrostachus cinerea & Fabaceae & 37 & 13.75 & 1.09 & 12.49 & 18 & 19.89 & 46.13 \\
\hline Pterocarpus lucens & Fabaceae & 54 & 17.14 & 0.25 & 22.74 & 15 & 14.15 & 54.03 \\
\hline Anogeissus leiocarpa & Combretaceae & 30 & 11.67 & 0.2 & 2.34 & 6 & 3.3 & 17.31 \\
\hline Syzygium guineense & Myrtaceae & 6 & 2.37 & 0.62 & 7.11 & 11 & 6.04 & 15.52 \\
\hline Tamarindus indica & Fabaceae & 9 & 3.46 & 0.37 & 4.25 & 9 & 4.95 & 12.66 \\
\hline Piliostigma thonningii & Fabaceae & 5 & 2 & 0.29 & 3.37 & 6 & 3.3 & 8.67 \\
\hline Ficus sycomorus & Moraceae & 4 & 1.64 & 0.34 & 3.92 & 5 & 2.72 & 8.28 \\
\hline Flueggea virosa & Euphorbiaceae & 6 & 2.55 & 0.12 & 1.37 & 7 & 3.85 & 7.77 \\
\hline Ficus lutea & Moraceae & 6 & 2.19 & 0.08 & 0.88 & 5 & 2.75 & 5.82 \\
\hline Asparagus flagellaris & Asparagaceae & 2 & 0.91 & 0.22 & 2.58 & 4 & 2.2 & 5.69 \\
\hline Combretum collinum & Combretaceae & 92 & 21.1 & 0.1 & 38.35 & 4 & 22.22 & 81.67 \\
\hline Oxytenanthera abyssinica & Poacea & 4 & 1.45 & 0.1 & 1.15 & 3 & 1.65 & 4.25 \\
\hline Sterculia africana & Sterculiaceae & 3 & 1.28 & 0.02 & 0.19 & 4 & 2.2 & 3.67 \\
\hline Pennisetum thumbergii & Poacea & 2 & 0.91 & 0.03 & 0.36 & 4 & 2.2 & 3.47 \\
\hline Grewia velutina & Tiliacea & 1 & 0.36 & 0.03 & 0.3 & 2 & 1.1 & 1.76 \\
\hline Phoenix reclinata & Aracaceae & 1 & 0.36 & 0.02 & 0.26 & 2 & 1.1 & 1.72 \\
\hline Boswellia papyrifera & Burseraceae & 1 & 0.36 & 0.02 & 0.19 & 2 & 1.1 & 1.65 \\
\hline Hyparrhenia filipendula & Poacea & 1 & 0.18 & 0.04 & 0.52 & 1 & 0.55 & 1.25 \\
\hline Ximenia americana & Olacaceae & 1 & 0.18 & 0.01 & 0.1 & 1 & 0.55 & 0.83 \\
\hline Clerodendrum alatum & Verbanacea & 1 & 0.18 & 0 & 0.02 & 1 & 0.55 & 0.75 \\
\hline Combretum hartmanianum & Combretacea & 76 & 28.35 & 3.8 & 33.25 & 69 & 15 & 76.6 \\
\hline
\end{tabular}

\section{Density, Frequency and Dominance}

The densities of all forage species, including seedlings, were 1216 stems ha $^{-1}$ (Tables-2). Few of the species dominated the woody vegetation and exhibited higher frequency values. In the study area Combretum colinum, Lonchocarpus laxiflorus, Terminalia laxiflora, Acacia polycantha and Ziziphus mucronata were the five relatively abundant forage species (Table-2). However, Phoenix reclinata, Clerodendrum alatum, imenia americanaand Grewia velutina, were represented with few individuals. At Guba, the majority of the forage species exhibited high density values (Table-2). However, the species richness values at the current study sites are far lower than those reported from Combretum-Terminalia forests of Anbessa forest of Assosa district [18] and of Wisin woodland of Bullen districts [19]. 


\section{Importance Value Index}

The Importance Value Index (IVI) values of all the forage species ranged between 0.31 (Strychnos innocua) and 81.67 (Combretum colinum). The most dominant woody species were Acacia polycanta, Hyphaene thebiaca, Lonchocarpus laxiflorus, Lanea. fruticosa, Pilostigma thunningii and Acacia senegal. Species with the least values of IVI were Clerodendrum alatum and Ximenia Americana (Table-2). The forage plant species reported from Guba are among the woody species with relatively high ecological importance, which is clearly reflected in their contribution to the overall IVI of the study sites. Similar results were also reported from Metema districts in Amhara Regional State where woody species contributed $65 \%$ and $75 \%$ of the total IVI, respectively [17].

\section{Utilization of plants for livestock feeding}

The interviewed farmers (agro-pastoralists) were able to identify which plant species and which vegetative part was favoured by which class of livestock (Table-2). The farmers, however, named these trees and shrubs in their vernacular language (Table-1).

Acacia hecatophylla, Pilostigma thonnongii, Dicrostachus cinerea was the most known tree species as indicated by 100 percent of respondents $(n=30)$. Some farmers collect pods of this tree species and keep them at their homes for the purpose of feeding calves and sick animals which cannot walk long distances in search of feed and water during the dry season. Unfortunately, no grinding or any other physical treatment was reported to be practised for the purpose of improving the nutritive value of the pods. Reasons given to the question as to why they do not grind the pods varied. Some indicated that the work is laborious especially for those with large herds of cattle. However, the majority did not know if this could be of value in feeding practices. During dry season when all the grasses burnt out the fallen dry leaves and pods of the family Fabaceae were known to be consumed whit no choices by the local breeds of the area to transit the harsh environment of Guba area (Figure-2). The study indicated that all the local breeds would like to be collectors of the fallen leaves of the drier area which opposes the natural habit of the animals. However, study by Marissa Ames, 2020 indicated that If forage is limited or unavailable due to seasonal conditions, bad weather, or limited pasture space, goats should be fed good hay (free-choice) from a manger or feeder. Hay for goats can be either legume hay (alfalfa or clover) or carbonaceous hay (timothy, brome, orchard grass, mixtures). Legume hay is pricier but has higher nutrition. It's an excellent feed for pregnant or lactating does, and kids. Grass hay is less nutritious and also less expensive, so homesteaders often feed a 50-50 grass-legume mix. All hay should be fine-stemmed, leafy, and green in color. Choose hay meant for horses rather than cows.

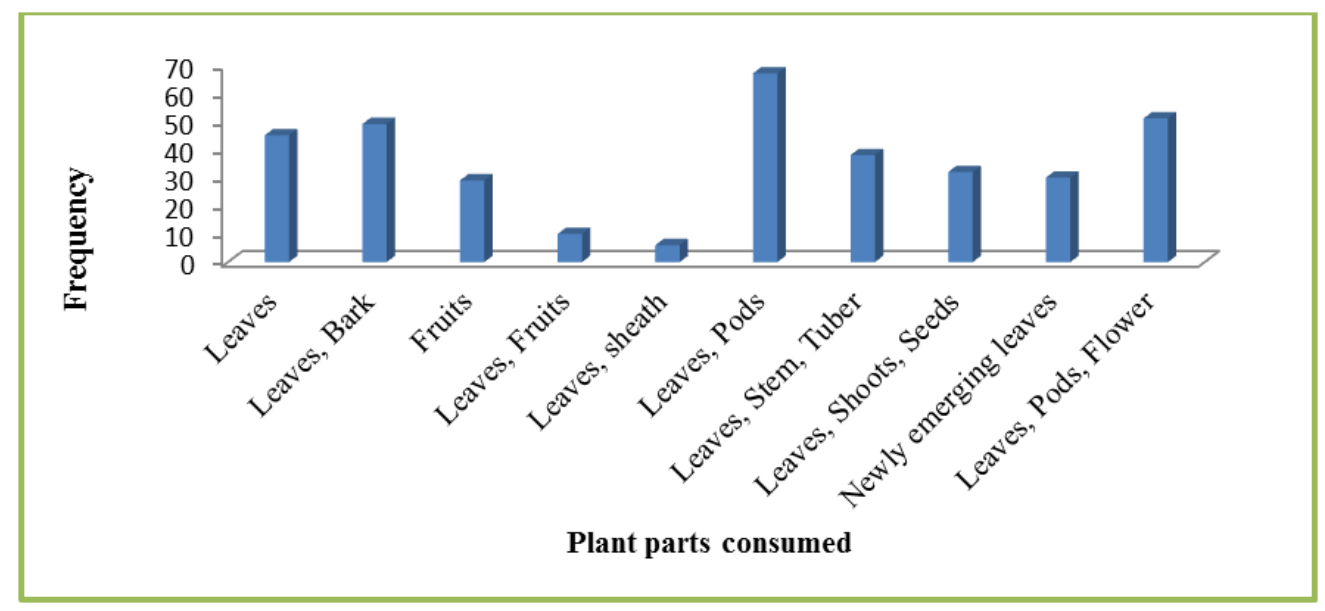

Fig-2: Parts of the forage plants preferred by the local breed during dry season

Apart from Acacia hecatophylla and Dichrostachys cinerea Anogeissus leiocarpa was reported to be known and used by all of respondents $(n=30)$. Its dry leaves were reported to be favoured particularly by small ruminants such as goats.

Other high ranking species were Lonchocarpus laxiflorus, Acacia species, Hyphenea thebiaca and Ziziphus mисronata were also mentioned and utilized for livestock feeding. 
Table-3: Knowledge on utilization of some plant species for livestock feeding in Guba district

\begin{tabular}{|c|c|c|c|}
\hline Local Name (Gumuzigna) & Plant species & Animal species & Favoured plant parts \\
\hline Amberta & Andropogon schirensis & Cattle, Goats, sheep and Donkeys & Leaves \\
\hline Adegila & Streospermum kunthianum & Cattle, Goats, Donkeys & Leaves, Bark \\
\hline Anderkukuwa & Strychnose spinosa & Donkey, Goats & Fruits \\
\hline Hanguga/Hangua & Ziziphus abyssinica & Cattle, Goats & Leaves, Fruits \\
\hline Siya/Gaba & Ziziphus mucronata & Cattle, Goats & Leaves, Fruits \\
\hline Antutiya & Solanum alatum & Goats & Leaves \\
\hline Babegoha/Bogoha & Terminalia macroptera & Cattle, Goats & Leaves \\
\hline Babenga & Hyphaene thebiaca & Cattle, Donkeys & Leaves, Fruits \\
\hline Bambeluwa & Entada africana & Goats & Leaves \\
\hline Bambuta & Annona senegalensis & Cattle, Goats & Leaves, Fruits \\
\hline Banja & Cordia africana & Cattle, Goats, Sheep & Leaves, Fruits \\
\hline Bewa & Lonchocarpus laxiflorus & Cattle, Goats & Leaves \\
\hline Begiya & Strychnos innocua & Donkey, Goats & Fruits \\
\hline Bora & Terminalia laxiflora & Cattle, Goats & Leaves \\
\hline Bembeda & Maytenus senegalensis & Cattle, Goats & Leaves \\
\hline Bidiguwa & Hyparrhenia anthistirioides & Cattle, Goats, Sheep, Donkeys & Leaves, sheath \\
\hline Biilga & Lannea welweschii & Cattle, Goats & Leaves \\
\hline Mamusa & Cymbopopogon caesuis & Cattle, Goats, Sheep, Donkeys & Leaves \\
\hline Chaya & Pterocarpus lucens & Goats & Leaves \\
\hline Dhoga & Tamarindus indica & Cattle, Goats, Donkeys & Leaves, Pods \\
\hline Mecha & Piliostigma thonningii & Cattle, Goats, Sheep & Leaves, Pods \\
\hline Fuqa & Ficus sycomorus & Cattle, Goats, Sheep, Donkeys & Leaves, Fruits \\
\hline Asiya & Ficus lutea & Cattle, Goats, Sheep, Donkeys & Leaves, Fruits \\
\hline Bambichowa & Asparagus flagellaris & Cattle & Leaves, Stem, Tuber \\
\hline Engifa & Combretum collinum & Cattle, Goats, Sheep & Leaves \\
\hline Elta/Enta & Oxytenanthera abyssinica & Cattle, Goats, Sheep, Donkeys & Leaves, Shoots, Seeds \\
\hline Etissayaquwa & Pennisetum thumbergii & Cattle, Goats, Sheep, Donkeys & Leaves, Sheath \\
\hline Gideya & Grewia velutina & Cattle, Goats, Sheep & Leaves, Fruits \\
\hline Hesiniya & Hyparrhenia filipendula & Cattle, Goats, Sheep, Donkeys & Leaves, Sheath \\
\hline Heya & Ximenia americana & Cattle, Goats & Newly emerging leaves \\
\hline Jipiwa/Chamda & Combretum hartmanianum & Cattle, Goats & Leaves \\
\hline Meela & Acacia seyal & Cattle, Goats, Sheep, Donkeys & Leaves, Pods, Flower \\
\hline Qota & Balanitus aegyptiaca & Cattle, Goats, Sheep & Leaves, Fruits \\
\hline Quatsirqa & Acacia hecatophylla & Cattle, Goats, Sheep, Donkeys & Leaves, Pods, Flower \\
\hline Sasiqida & Cynodon nlemfuensis & Cattle, Goats, Sheep, Donkeys & Leaves \\
\hline Sipe & Acasia polyacantha & Cattle, Goats, Sheep & Leaves, Pods \\
\hline Siqida/Si-Eda & Securidaca longepedunculata & Cattle, Goats & Newly emerging leaves \\
\hline Songah & Ziziphus mauritiana & Cattle, Goats, Sheep & Leaves, Seeds \\
\hline Dimquri & Ipomoea eriocarpa & Cattle & Whole part \\
\hline Tara/Geret & Acacia senegal & Cattle, Goats, Sheep & Leaves, Pods \\
\hline Mureb & Pennisetum unisetum & Cattle, Goats, Sheep, Donkeys & Whole part \\
\hline Kota & Gardenia ternifolia & Cattle, Goats & Leaves, Fruit \\
\hline Weela & Dicrostachus cinerea & Cattle, Goats & Leaves, Pods \\
\hline Weela & Flueggea virosa & Goats & Leaves \\
\hline Sigah & Anogeissus leiocarpa & Goats & Leaves \\
\hline \multirow[t]{2}{*}{ Insiya } & Ficus vasta & Cattle, Goats, Sheep, Donkeys & Fruits \\
\hline & Saspania spp & Cattle, Goats, Sheep & Leaves, Pods \\
\hline Bufa & Unidentified grass & Cattle & Whole part \\
\hline Moringa & Moringa Olifera & Cattle, Goats, Sheep, Donkeys & Leaves, Flower, Barks \\
\hline
\end{tabular}

The response given by the interviewed farmers on their experiences on utilization of various plants were comparable to observations made by Backlund and Bellskong [20] who closely followed the herds of livestock grazing in selected farms in Metema district, Amhara region. 


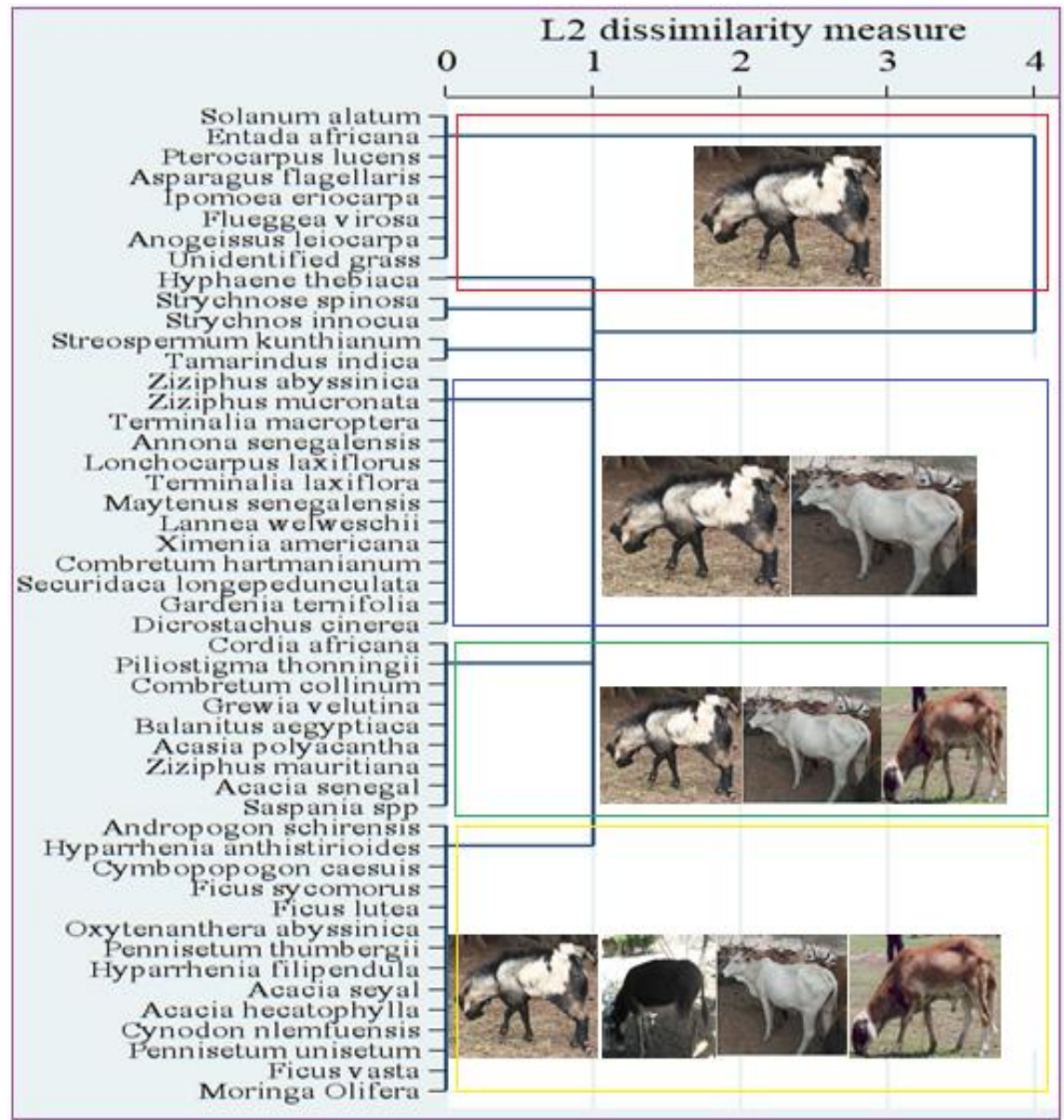

Fig-3: Dendrogram showing the classification of forage plant species based on the preferences by local animal breeds. The horizontal axis represents the distance or dissimilarity between clusters and the vertical axis represents the local animal breeds and clusters

Particularly local goats' breeds of the study area were known to feed on various feed resources than other breeds. Moreover, Bigariya cattle breeds were also know to feed on various similar plant resources hence adapted to harsh environmental condition known in western Ethiopia (Figure-3). Similarly the study of Jackson, 2008 stated that "Goats have a huge diversity of other plants to choose from than ones we would normally consider traditional forages like fescue, orchard grass, white and red clover, etc." To the contrary mixed grazing particularly goats with cattle is no common in other areas of the world this is because "When goats graze first and then the cattle come in, they are doing what we call 'clean up grazing' in the pasture. At the end of the first grazing season, it was found that cattle that followed goats weighed on average 30 pounds less than cattle that were grazing with goats all the time [21]."

Table-1: ANOVA Results

\begin{tabular}{|l|l|r|l|l|l|}
\hline \multicolumn{7}{|c|}{ Analysis of Variance } \\
\hline Source & SS & df & MS & F & Prob > F \\
\hline Between groups & 194.417687 & 11 & 17.6743352 & 2.93 & 0.0070 \\
\hline Within groups & 223.133333 & 37 & 6.03063063 & & \\
\hline Total & 417.55102 & 48 & 8.69897959 & & \\
\hline
\end{tabular}

As illustrated in Table-4 above, the significance value in testing the reliability of the model for the relationship between the local animal breeds with their sources of feed materials (plant species) was obtained as 0.007 which is less than 0.05 the critical value at $95 \%$ significance level. That means most of the local breeds feed differently on different parts of plant materials that are available during dry season in the study area. This statement is similar with the study of Jackson Ky, 2008 [21] stating that "Goats have a huge diversity of other plants to choose from than ones we would normally consider traditional forages like fescue, orchard grass, white and red clover, etc." .

\section{Veterinary Use of plant species}

Some trees and shrubs are utilized by agro-pastoralists in treatment of animal diseases and disorders. For example, the stem of a mistilto plant "Ewa" is pounded and mixed with water. The material is squeezed out into the 
reproductive tract of a cow leaving the mother liquor to induce the expulsion of the retained placenta. On the other hand, pounded barks of Cordia Africana and roots of Securidaca longepedankulata is used in treatment of diarrhoea and common cold cases of goats. Moreover the sheath of Hyphenea thebiaca is used to treat the eye disease of Goats, sheep and cattle

Table-5: Veterinary use of some trees and shrubs

\begin{tabular}{|l|l|l|}
\hline Plant species & Animals & Comments \\
\hline Cordia africana & Goats & Bark powdered and mixed with water to treat diarrheal diseases \\
\hline $\begin{array}{l}\text { Securidaca } \\
\text { longepedanculata }\end{array}$ & Goats & $\begin{array}{l}\text { Chopped and squeezed roots extracts were used to treat respiratory diseases } \\
\text { (e.g. common cold) }\end{array}$ \\
\hline Hyphaene thebiaca & Cattle & Chopped sheath of Hyphaene is used to treat eye diseases \\
\hline Euphorbia sp & Cattle & Stem pound and mother liquor used (Mistilto) to expel retained placenta \\
\hline
\end{tabular}

\section{Treatment of Livestock Products}

Some farmers use trees and shrubs to enhance livestock products such as milk. Leafs and Wood from some of the plant species (Table-4) is used to feed the animals specially caws to increase the milk content and even its smoke is believed to increase the shelf life of milk and to impart desirable flavours to the "clotted" and concentrated product. Studies conducted at Sokoine University of Agriculture (SUA) on traditional smoking of milk practised by different tribes in Tanzania show that smoke treatment inhibits growth and activity of mesophyllic and thermophilic lactic acid bacteria, although the treated product might not be favoured by everybody tasting the milk [22].

Table-6: Plant species used as milk enhancer in Guba district

\begin{tabular}{|l|}
\hline Ipomoea eriocarpa \\
\hline Asparagus flagellaris \\
\hline Bufa grass \\
\hline Hyparrhenia anthistirioides \\
\hline
\end{tabular}

\section{The impact of Seasonal Dynamics and management on the availability of Forage Plant Species}

The owners and herders of the study area identified a total of 49 dominant forage species distributed over the seasonal grazing areas (Table-2) and were also able to rank their abundance in the vegetation across seasons. A significant proportion of pastoralists/owners stated that there is a shortage of forage plant species in March, April and May because of late burning which massively distracts the whole part of the plants. Moreover, a decline in wet weight forage quantity is not a problem to Bigariya cattle breed because mostly these breeds are not like other breeds in that they adopted to browse on thorny and longer dominant Acacia species of the area.

Since animals feed resource is not a problem the pastoralists keep their herd of cattle in communal grazing, and herd splitting based on the number of cattle's owned. To the contrary Pastoralist households across East Africa face major livestock losses during dry periods that can cause persistent poverty [22].

\section{ACKNOWLEDGEMENTS}

We are grateful to the woreda experts, the local administration and people who supported and facilitated the field data collection. We would like to thank the Assosa Biodiversity Center for the financial and facility support. We also acknowledge gratefully the anonymous reviewer for the valuable comments on an earlier version of this article.

Disclosure Statement: No potential conflict of interest was reported by the authors.

\section{REFERENCES}

1. Herlocker, D. (1999). Rangeland resources in Eastern Africa: Their ecology and development. GTZ German technical co-operation, Nairobi, Kenya.

2. Zhou, K., \& Doyle, J. C. (1998). Essentials of robust control (Vol. 104). Upper Saddle River, NJ: Prentice hall.

3. Trollope, W. S. W., Trollope, L. A., \& Bosch, O. J. H. (1990). Veld and pasture management terminology in southern Africa.

4. Friedel, M. H., Laycock, W. A., \& Bastin, G. N. (2000). Assessing rangeland condition and trend. In: Field and laboratory methods for grassland and animal production research. (Eds. Mannetje, L. „t. and Jones, R.M.) CAB International, UK. 227-261.

5. Danckwerts, J. E., \& Tainton, N. M. (1996). Range management: optimizing forage production and quality. Bulletin of the Grassland Society of Southern Africa (South Africa).

6. Central Statistics Authority (CSA). (2012). Population and Housing Census: Administrative Report. Addis Ababa. 
7. Kent, M. and Coker, P. (1992) Vegetation Description and Analysis: A Practical Approach. CRC Press, Boca Raton, 363 p.

8. Peters, E. E. (1996). Chaos and order in the capital markets: a new view of cycles, prices, and market volatility. John Wiley \& Sons.

9. Teketay, D. (1997). Seedling populations and regeneration of woody species in dry Afromontane forests of Ethiopia. Forest ecology and management, 98(2), 149-165.

10. Ogbazghi, W., Rijkers, T., Wessel, M., \& Bongers, F. (2006). Distribution of the frankincense tree Boswellia papyrifera in Eritrea: the role of environment and land use. Journal of Biogeography, 33(3), 524-535.

11. Sop, T. K., Oldeland, J., Schmiedel, U., Ouedraogo, I., \& Thiombiano, A. (2011). Population structure of three woody species in four ethnic domains of the sub- sahel of Burkina Faso. Land Degradation \& Development, 22(6), 519-529.

12. Hedberg, I., \& Edwards, S. (1989). Vol. 3: Pittosporaceae to Araliaceae.

13. Hedberg, I., Edwards, S., \& Phillips, S. (1995). Flora of Ethiopia and Eritrea, Vol. 7: poaceae (gramineae). AAU.

14. Edward, S., Demisew, S., \& Hedberg, I., editors. (1997). Flora of Ethiopia and Eritrea. Hydrocharitaceae to Arecaceae. Vol. 6. Addis Ababa: The National Herbarium, Addis Ababa University and Uppsla: Department of Systematic Botany, Uppsala University.

15. Edwards, A. C., Cook, Y., Smart, R., \& Wade, A. J. (2000). Concentrations of nitrogen and phosphorus in streams draining the mixed land- use Dee Catchment, north- east Scotland. Journal of Applied Ecology, 37, 159-170.

16. Eshete, A., Sterck, F., \& Bongers, F. (2011). Diversity and production of Ethiopian dry woodlands explained by climate- and soil-stress gradients. Forest Ecol Manage. 261:1499-1509.

17. Worku, A., Teketay, D., Lemenih, M., \& Fetene, M. (2012). Diversity, regeneration status, and population structures of gum and resin producing woody species in Borana, Southern Ethiopia. Forests, Trees and Livelihoods, 21(2), 85-96.

18. Tamene, Y. (2016). Plant Diversity and Carbon Stock Analysis along Environmental Gradients: the case of Gergeda and Anbessa Forestsin Western Ethiopia. PhD dissertation Addis Ababa University Addis Ababa, Ethiopia.

19. Dereje, M., \& Birhanu, A. (2012). The diversity and conservation of edible wild-food plants in Wisin Woodland (WW) in Bullen District, North West of Ethiopia. MSc thesis Bahirdar University Bahir Dar Ethiopia.

20. Olson, L., Backlund, E. O., Ebendal, T., Freedman, R., Hamberger, B., Hansson, P., ... \& Sydow, O. (1991). Intraputaminal infusion of nerve growth factor to support adrenal medullary autografts in Parkinson's disease: oneyear follow-up of first clinical trial. Archives of Neurology, 48(4), 373-381.

21. Jackson, K. (2008). Can goats and cattle graze same fields?. University of Kentucky College of Agriculture. 324.

22. Chenyambuga, S. W., Goromela, E. H., Ryoba, R., \& Kurwijila, R. L. (1993). A study on the effect of traditional African smoke treatment of milk on the organoleptic and keeping quality of sour milk. Paper presented at the first Biennial workshop of Cattle Research Network, ILCA, Addis Ababa, Ethiopia, 17-21.

23. Vrieling, A., Meroni, M., Mude, A. G., Chantarat, S., Ummenhofer, C. C., \& de Bie, K. C. (2016). Early assessment of seasonal forage availability for mitigating the impact of drought on East African pastoralists. Remote sensing of environment, 174, 44-55.

Citation: Dereje Mosissa et al (2021). An Assessment of the Diversity of Indigenous Forage Plant Species of the Dry Season in Dry lands of North Western Ethiopia: Implication for their Conservation and Sustainable Use. South Asian Res J Bio Appl Biosci, 3(1), 1-10. 